\title{
Enhancing English Language Learners' Listening Comprehension through Listening Strategies Instruction
}

\author{
Sitti Hadijah ${ }^{\text {1) }}$, Shalawati ${ }^{2)}$ \\ ${ }^{1}$ Universitas Islam Riau \\ email: sittihadijah@edu.uir.ac.id \\ ${ }^{2}$ Universitas Islam Riau \\ Email: shalawati@edu.uir.ac.id
}

\begin{abstract}
This paper is a part of research project carried out to enhance the English learners' listening comprehension through listening strategies instruction. The research worked on classroom action research design, conducted in two cycles by involving a group from fresh year English learners in English study program of Teacher Training and Education Faculty, Universitas Islam Riau on 2017/2018 academic year. The findings revealed gradual improvement of the students' performances in doing the listening tests. At the first cycle, the students could reach 25 out of 40 questions, in which this number is four points less than the students' achievement in cycle 2. Then, in range 10-25 questions of correct answers in cycle 1 could be reached by 24 students, while in cycle 2 , there were 32 students got correct answers at that range. Furthermore, there were 6 students could reach less than 10 questions correctly, beside that there were only 3 students in cycle 2. In conclusion, there have been improvement of the students' achievements in listening tasks provided in all meetings during cycle 1 and 2 . Although they found challenges in completing the tests, the teachers' assistances in guiding them to apply some strategies contributed towards the improvement of their performances in listening.
\end{abstract}

Keywords: enhancing, listening comprehension, listening strategies instruction

\section{Meningkatkan Keterampilan Menyimak Mahasiswa \\ Bahasa Inggris Melalui Bimbingan Strategi Menyimak}

\begin{abstract}
Abstrak
Artikel ini merupakan bagian dari penelitian yang dilakukan untuk meningkatkan kemampuan menyimak para mahasiswa/i yang memperlajari bahasa Inggris, yang dilakukan melalui bimbingan penggunaan strategis menyimak. Penelitian ini dilaksanakan dengan rancangan penelitian tindakan kelas yang terdiri dari dua siklus dengan melibatkan sekolompok mahasiswa di Program Studi Pendidikan Bahasa Inggris, Fakultas Keguruan dan Ilmu
\end{abstract}


Pendidikan, Universitas Islam Riau, pada tahun akademik 2017/2018. Hasil penelitian menunjukkan bahwa adanya peningkatan secara perlahan selama kegiatan penelitian dilaksanakan. Pada siklus pertama, mahasiswa mampu menjawab 25 dari 40 soal yang diberikan, yang mana jumlah tersebut lebih rendah jika dibandingkan dengan hasil yang diperoleh pada siklus pertama. Selanjutnya, sebanyak 10-25 jawaban yang benar dapat diberikan oleh 24 mahasiswa di siklus pertama, sedangkan pada siklus kedua berjumlah 32 mahasiswa. Berikutnya, ada 6 mahasiswa yang hanya bisa menjawab kurang dari 10 pertanyaan dengan benar dan hanya 3 mahasiswa di siklus kedua. Sehingga dapat disimpulkan bahawa terjadi peningkatan kemampuan mahasiswa dalam menyimak yang didasaarkan pada hasil tes menyimak yang telah diberikan pada siklus pertama dan kedua. Meskipun mahasiswa menghadapi kesulitan dalam menyelesaikan tes yang diberikan, mereka mengemukakan bahwa bimbingan ataupun arahan yang terkait dengan penggunaan strategi-strategi menyimak telah membantu mereka dalam menyelesaikan tantangan pada tes menyimak yang mereka lakukan.

Kata Kunci: meningkatkan, kemampuan menyimak, bimbingan strategi menyimak.

\section{INTRODUCTION}

In English language teaching context, listening skill still appears as one of challenging skills to be mastered by the students, this matter is influenced by several factors; one of the common problems is the students' lack of listening practices that make them getting difficulties to understand information that they listen to. Those who get difficulties in their listening activity usually say that they do not understand what the speakers in the audio or video are talking about, unclear pronunciation, and high speech rate of the speakers. All of the reasons describe that the students' real problem in listening is because of having limited experience in listening practices.

Although English subject is taught twice a week with ninety minutes duration for every meeting in many classrooms in Indonesia, it does not guarantee that the students get adequate practices for all of the language skills; speaking, reading, writing, and listening. Most of the students in English classroom learn a lot how to read and write, but they have limited experiences how to speak and understand aural information. Furthermore, the students also rarely practice their listening activities out of the class. In addition, the students just depend on their teacher to facilitate them to practice their listening skill, while the teachers rarely teach them.

Based on six years experiences as English teacher in a Private Vocational High School, researcher was rarely to teach listening in the class because it was one of the most difficult skills to be taught. When she tried to play a recording of general English conversation in the class, there were 
only a few students who could really understand about the conversation and the rest of them just said that they did not know what the speakers were talking about. Then, she did get difficulties to find out appropriate listening materials to train the students in developing their listening skill.

Obviously, the students' limited listening strategies can be a big influence towards their performances in listening. It can be a big problem for the students when they do not know what they have to do to solve some problems in their listening activities. Most of them have limited understanding about particular strategy that they can implement when listening. In this case, it is very important for teachers to introduce and guide the students to apply appropriate listening strategies to reach their objectives in listening. Besides facilitating the students to have more experiences in listening performances, the teachers need to help them to apply the best strategy in the listening activities. The students' familiarity with some listening strategies can make them to be independent and successful learners who can figure out all their problems in listening.

In line with the common problems of the learners in listening, extensive and intensive listening activities are required by the students as an effort to enhance their listening comprehension. In technology based era nowadays, the learners should not only depend on the teachers to bring the learning materials for them, but they also need to be autonomous learners to easily enhance their listening skill. There are numerous free access sites of educational videos and audios nowadays, so having good listening comprehension should not be a matter.

Besides having daily practices on extensive and intensive listening activities, the learners also need to be familiar with some learning strategies that they can apply to help them solving some problems that they probably face during their listening activities. Numerous strategies known by the learners will ease them to figure out some challenges that they encounter. It means that the learners should know about what they have to do to be successfully in their listening activities.

In short, having good listening skill can guide the students to easily develop the other listening skills, so it is very essential to have regular listening practices, either extensively or intensively. Hence, the students have to be guided to apply listening strategies to figure out some listening comprehension matters and enhance their skill in listening. Finally, this paper depicts to what extent listening strategies instruction can enhance the English students' listening comprehension, and factors influence the enhancement of the students' listening comprehension through listening strategies instruction at Universitas Islam Riau.

\subsection{Listening Comprehension}

Listening skill has important roles to all other skills because it can significantly influence for language development, (Bang and Hiver, 2016). Listening activities are 
dominantly used in various contexts of communication, neither in social nor academic environment. It is basic skill that can enhance the learners' ability to master a language because it provides basic components of language and cognitive development, Malkawi (2010). Learners' failures in listening activities will affect their communication skill. Vandergrift and Goh (2012) defined listening as an activity with purposeful process to construct meaning from aural input. It means that listening activities are not only about listening to information, but the listeners/learners have to be able to understand the information. Hence, listening activities closely relate to listening comprehension.

Gilakjani and Ahmadi (2011) stated that English foreign language (EFL) learners usually face serious problems in listening comprehension as the learners have limited experiences in practicing the skill. Many students state that listening instructions in the classrooms have less emphasized which is compared to other skills, such as reading and writing. Hadijah and Shalawati (2017) in their study about listening comprehension hindrances of EFL learners also found that lack of listening practices at schools as main factor affecting the learners' listening comprehension. Then, it links to the learners' unfamiliarity of speakers' speech rate, pronunciation, and unknown vocabulary. Even though English subject had been introduced to the learners since at elementary or junior high school level, they were rarely to practice the skill. So, they encounter serious problems in listening and have lack of understanding about some ways or strategies that can be implemented

In short, to become skilledlearners in English, particularly in English listening, the learners have to be able to apply appropriate listening learning strategies to figure out some problems that might appear during the process of learning.

\subsection{Listening Strategies Instruction}

Strategy Instruction can be defined as an activity of teaching some types of strategies to learners with an objective of enhancing their learning outcome, (Oxford, 2011). It needs to be done by teachers as an effort to improve the learners' performances in learning and prepare them to be independent learners who can figure out some problems during their learning process through the appropriate strategies that they have known.

In the field of listening, learners have greatly varying levels of success in listening, particularly for L2 listening: some learners have good proficiency in listening, while others often encounter some difficulties in listening, (Bang and Hiver, 2016). Richard (2008) states that strategies used by listeners in listening activities can influence their success in listening. In this case, the learners need to know well about listening strategies to enhance their listening performances. Teaching some strategies to the learners can be done by instructors to help the learners to get effective ways of approaching and managing the listening tasks, (Richard (2008)) 
Listening strategies refer techniques used by learners to comprehend and recall listening input. The strategies can be classified by how listeners process the input; top-down strategies, bottom-up strategies, and metacognitive strategies. According to Yeldham \& Gruba (2014) state that top-down strategies relate to the use of context and prior knowledge, such as topic, genre, culture, and other fields of knowledge in long term memory. Then, bottom-up strategies involve listeners in using lower-level, linguistic information from the text, such as word recognition and sentence parsing, that provides the raw data build meaning. Moreover, metacognitive strategies relate to planning, monitoring, and evaluation.

Actually, there have been several studies investigated the effect of strategy on learners' listening comprehension, such as Nogueroles (2017) in his research about the effect of listening strategies instruction towards Hongkong students' general strategic behavior. He structured three cycles of strategies instruction to the students by introducing metacognitive strategies, cognitive strategies, and socio-affective strategies. The study revealed that there was minor change of general listening strategic behavior of the learners since they did not have adequate time to reflect, practice, evaluate, and transfer the use of the listening strategies. So, this study provides meaningful information to the teachers to effectively run listening strategies instruction. Meanwhile, Graham \& Vanderplank, R. (2011) state that strategy instruction can significantly affect learners' listening comprehension. Vandergrift (2007) stated that skilledlisteners use more metacognitive learning strategies than the lessskilled counterparts. Mohseny and Raeisi (2009) explored the relationship between language proficiency of Iranian EFL learners and their listening strategy use. Statistical analysis showed a significant positive correlation between proficiency level and listening strategy use. Hence, the learners need to be given a range of listening strategies that they can select based on listening tasks

Buck (2001) categorized two types of listening strategies; cognitive strategy and meta-cognitive strategies.

(1) Cognitive strategies are defined as mental activities relate to comprehending and storing input in working memory or long-term memory for later retrieval. Cognitive strategies consist of comprehension processes (processing linguistics and non-linguistic input), storing and memory processes (storing of linguistics and non linguistics input in working memory), and using and retrieval processes (accessing memory to be readied for output. (2) Metacognitive strategies relate to conscious or unconscious mental activities that perform an executive function in the management of cognitive strategies in which consist of assessing, monitoring, self-evaluating, selftesting.

As an effort to raise the students' awareness about specific strategies of listening comprehension, teachers should facilitate conscious practice in using the strategies, Nogueroles (2017). It means that instruction to recognize and use the strategies should be provided for the students. The teachers have to know 
what they have to do during the instruction. Nogueroles (2017) in his study about the effect of listening strategies instruction on Hongkong students' general strategic behavior structured six phases of listening strategies instruction ; (1). Awareness-raising, (2). presentation, (3). planning, practice, monitoring, and evaluation I, (4) planning, practice, monitoring, and evaluation II, (5). planning, practice, monitoring, and evaluation III, (6). expansion. The description of the phases can be found in the following information:

\section{Six Phases of Listening Strategies} Instruction

1. Awareness-raising Help the students ware of the importance and effectiveness of using selected listening strategies

\section{Presentation}

Encourage the students to understand the name, objective, procedure, and context of using the strategies.

3. Planning, Practice, Monitoring, and Evaluation I

Give detail instruction and checklist guided and scaffold the development of the target strategies.

4. Planning, Practice, Monitoring, and Evaluation II

Reduce scaffoldings

5. Planning, Practice, Monitoring, and Evaluation III

Encourage the students to be independent to select appropriate strategies to complete the task given.

\section{Expand}

Transfer strategic behavior to other tasks and skills.

Goh and Yusnida (2006) in

Richard (2008) organized steps in guided meta-cognitive sequence in listening lesson. The steps consist of pre-listening activity, first listen, pair process-based discussion, second listen, whole-class process-based discussion. The detail description of the steps can be seen in the following information:

\section{Steps in guide meta-cognitive}

sequence in a listening lesson

\section{Step 1 : Pre-listening activity}

In pairs, students predict the possible words and phrases that they might hear. They write down their predictions. They may write some words in their first language.

\section{Step 2 : First Listen}

As the students listen to the text, they underline or circle those words or phrases (including first-language equivalents) that they have predicted correctly. They also write down new information they hear.

\section{Step 3 : Pair Process-Based}

\section{Discussion}

In pairs, students compare what they have understood and explained how they arrived at the understanding. They identify the parts that caused confusion and disagreement and make a note of the parts of the text that will require special attention in the second listen.

\section{Step 4 : Second Listen}

Students listen to those parts that have caused confusion or disagreement areas and make notes of any new information they hear.

Step 5 : Whole-class process-based discussion 
The teacher leads a discussion to confirm comprehension before discussing with students the strategies that they reported using second listen.

Adopted from Goh and Yusnida (2006) in Richard (2008)

Afterwards, Cross (2009) in his research about effects of listening strategy instruction on news videotexts comprehension provided several examples of strategies instruction, they are; planning strategy, selective attention strategy, self management strategy, selfevaluation strategy, elaboration strategy, inferencing strategy, imagery strategy, detection strategy, transfer strategy, note taking strategy, reconstituting strategy, cooperation strategy, question for clarification strategy, and self motivation strategy. All of the strategies provided to the students can facilitate them to practice in identifying the appropriate listening strategies that they can apply to support their listening comprehension.

In brief, giving listening strategies instruction can be an alternative ways to figure out learners' listening comprehension problems because there had been several studies proved the effectiveness of the instruction to enhance the students' listening skill. Moreover, there had been some procedures that can be implemented or developed by teachers who are interested in applying listening strategies instruction to help the learners to be skilled-listeners.

\section{METHOD}

This research worked on classroom action research design which was intended to enhance the students' listening comprehension, this study was conducted in two cycles with four meetings in every cycle, by involving a group from fresh year English learners in English study program of Teacher Training and Education Faculty, Universitas Islam Riau on 2017/2018 academic year.

\section{FINDING AND DISCUSSION}

Two cycles were run to find out the extent of listening strategies instruction in enhancing English language learners' listening comprehension. The first cycle was begun on $4^{\text {th }}$ November $-25^{\text {th }}$ November 2017, consisted of four meetings. Further information for both of the cycles is presented in the following detail:

\section{Planning}

As an essential phase in doing the research, planning was set a week before taking the action. Some documents, learning scenarios, and learning aids were prepared to support the research activity. Afterwards, the action, observation, and reflection were run in integrated activities. Detail description of is presented below:

\section{Actions \& Observation}

\section{The First Action, $4^{\text {th }}$ November 2017}

In pre-listening activity, the students were guided to identify one

Enhancing English Language Learners' Listening Comprehension through Listening Strategies Instruction 
of the factors influenced their performances on listening activities. The students realized that they needed to know about some strategies that could help them to successfully run the listening activities. Then, the students were asked to identify some strategies that they have known and applied in listening.

Afterwards, the learning activity was started by giving listening test to the students, they were asked to complete 10 questions from section 1 of IELTS test. The test was divided into two categories; part one (questions number 1-5) and part two (questions number 6-10). Since it was the first experience for the students to do the test, the students did not successfully complete all the questions given. Confusion in completing the test appeared as one of the students' challenges because they had not been familiar with the test format. Hence, the students were in doubt to apply the listening strategies to support their performances on listening. The result of the test could be seen in the following figure:

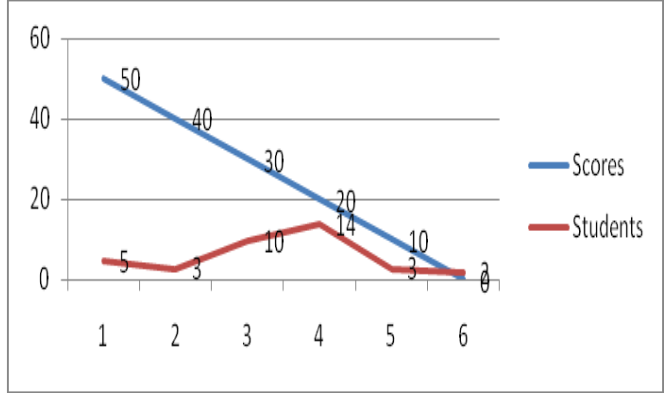

Figure 1: Students' Achievement in Listening test 1 (Cycle 1)

The lines above depict the students' achievement in completing listening comprehension test that consisted of 10 completion question.
In the test, the students have to write down one up two there words to complete a note based on the audio that they listened. Based on the students' achievement, the students could not successfully complete the test provided since there were only five out of thirty-seven students could reach 5 questions correctly. It means that the highest score was only 50 . Then, it was followed by $3,10,10,3$ students who could only get 40,30,20, and 10 scores respectively. Meanwhile, there were two students who completely cannot answer the questions. In this case, the students' performances on their first listening test revealed their problems in listening.

After knowing the students' achievement in the test, the researcher emphasized to them about the importance of applying some strategies to successfully complete all the listening tasks. In this case, the researcher distributed some list of listening strategies that could be applied by the students to enhance their performances in listening task. Through the observation, the researcher found that the most significant problems encountered by the students in their listening activity was influenced by limited vocabulary mastery. The students found that the task was tough because what they have no idea about what information that they have to complete in the task.

\section{The Second Action, 11 November 2017}

The first phase in day two meeting was begun by guiding the students to apply some listening strategies that they needed to 
complete the listening tasks. The strategies consisted of meta-cognitive, cognitive, and socio-affective strategies in which each of them can be very essential in the listening activities. After explaining about the strategies, the students seemed knowing what strategy that they had to apply in their listening activities.

In listening practice, the listening tasks were divided into two parts in which both of the parts are section one in listening IELTS consisted of 10 questions of completion test with 5 questions for each part. For the second meeting test. In doing the first part, the students still got difficulties to answer all of the questions, even though they had been familiar with some strategies that they had to apply. However, the students did not look confused to do the test because they previously had experienced in doing the same format of the test. In this case, the students perhaps got familiar with the strategies and test format, but a little anxious of the students when doing the test could be seen, so it might influence their performances on the listening test. The result of the listening test can be seen in the following figure:

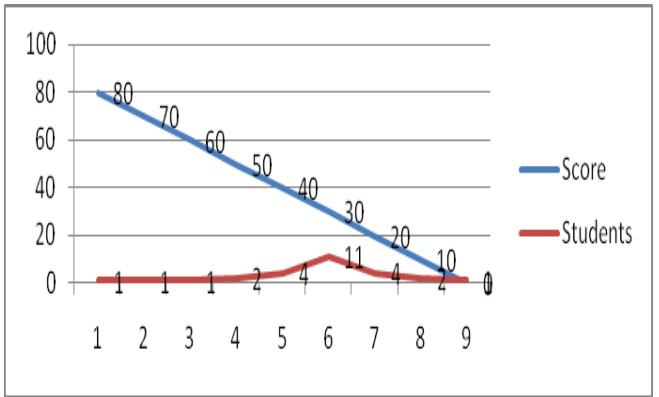

Figure 2: Students' Achievement in Listening Test 2 (Cycle 1)
The lines depict that the students' performances on the second listening task, the students score could go up to 80 even though it could only be reached by one student. Then, two other students could get 70 and 60. Meanwhile, most of the rest the students got lower score than 60 , the number of the students in this level approximately 91\%. In other words, most of the students still got toughness in completing the test. In this activity, most of the students could not correctly transfer the information on their answer sheet. A few students just let their answers blank because they had no idea about what they must write. While, some other students tried to complete the form, but unfortunately the information was not correctly written.

Based on the result of observation, the students were very focus on completing the task and eager to successfully answer all of the questions. It could be seen from the students enthusiasm to get the second opportunity to listen the audio for a second time because once listen was not enough for them to complete the task. Furthermore, in an interview conducted to a student in the class, she shared that their listening activity made her getting nervous because she had to complete the listening task which was not easy for her. Then, some other students quite enjoyed the learning activity even though they were not really familiar with the format. In addition, another student added that the teacher's guides before starting the listening activity helped her a lot to complete the test although he did get significant improvement compared to the previous test. The 
student said, "at least, my score improved two points in this test."

\section{The Third Action, 18 November 2017}

Learning activity was begun by discussing some strategies that the students should apply to help better in completing the third listening task. During the discussion session, one of the students shared that she could not well apply the strategy while she was working on the listening test. "the strategies seemed easy to be implemented, but they were not as simple as they seemed.", the student added. In this case, the students found great challenge to apply the strategies in their listening activity.

To help the students in solving their problems in applying the listening strategy, the students were informed to be calm on their listening activity. Through the observation done at the previous meetings, a few students who calmly did the test could show better performances in their listening test.After having discussion about what "do" and "don't" points that the students have to concern on their listening test, they were assigned to complete ten listening test about filling out a form of English learner who was looking for part time job. Some words and numbers have to be written correctly by the students. Further, the result of the test can be seen in the following table:

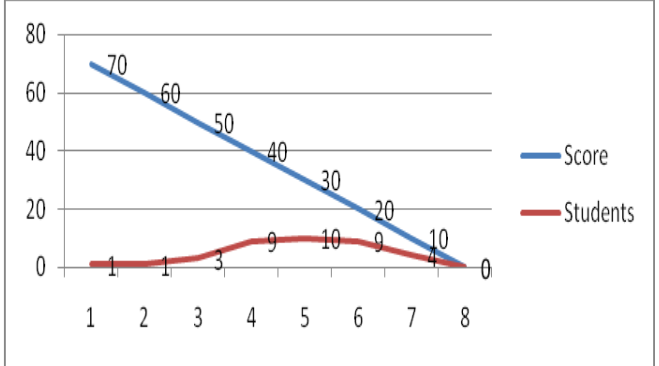

J-SHMIC, Vol 5, No 1, February 2018

\section{Figure 3: Students' Achievement in Listening Test 3 (Cycle 1)}

Based on the figure above, the result of the test was not really satisfying since the scores show that listening test was not easy for the students. Most of them failed to show better performance on the third listening test, as can be seen from the table, there were only two students could stayed on 60 and 70, while most of them only reached 10-50, accounted for 35 students were in this group. More students reached 40 and 30, there were 19 students in total. This finding significantly showed that there had not been any significant change of the students' performances on their listening skill.

Through the observation, the students did not have problem to apply their listening strategy, they just encountered significant problems to clearly listen to the information because one of the students said that she got really difficult to easily understand about what the speakers were talking about. She also said that the speakers spoke very quick, she terribly bad to understand the information. The problem runs in line with the result of filed note in which the students still showed confusion on her face in completing the form given. The students also get toughness in writing the required words and number perfectly, for instance; in one of the questions, the students had to write down "cleaner" as an answer, but many students failed to write the word, most of them just wrote "clean". This case revealed that the students have been familiar

Enhancing English Language Learners' Listening Comprehension through Listening Strategies Instruction 
with some words uttered by the speakers in the audio, but unfortunately they did not fully understand the communication context and failed to answer correctly.

In an interview, a student said that she had tried to apply some strategies that had been explained before to enhance their listening performances, she found the strategies worked for several numbers, and failed for some others. She considered that her failure was totally affected by her difficulties to catch the idea stated by the speakers. Then, another student shared that reading some clues before starting the listening test helped her a lot to complete the questions. The clues she found on the test construct her knowledge to predict what information that she might need to write on the answer sheet. In short, the students had applied some listening strategies to enhance their performance on the listening test even though the strategies have not properly worked on.

\section{The Fourth Action, $25^{\text {th }}$ November 2017}

The meeting was started by re-explaining to the students about listening strategies that the students could apply to enhance their performance in the further listening task. To ensure about the students' awareness towards the strategy, some questions about the name, objective, procedure, and contexts of using the strategies were given to the students. In this activity, the students could show their better understanding about the strategies since they actively participated to answer the questions.
Furthermore, the students were assigned to do fourth task of listening comprehension test and apply the strategies that they require to support her performances on the task. In the task, the students had to fill out a form about someone's home-stay application. It consisted of ten questions in which the students have to be complete the form with the appropriate words or numbers that they listened from the speakers in the audio. The following table presents the result of the test:

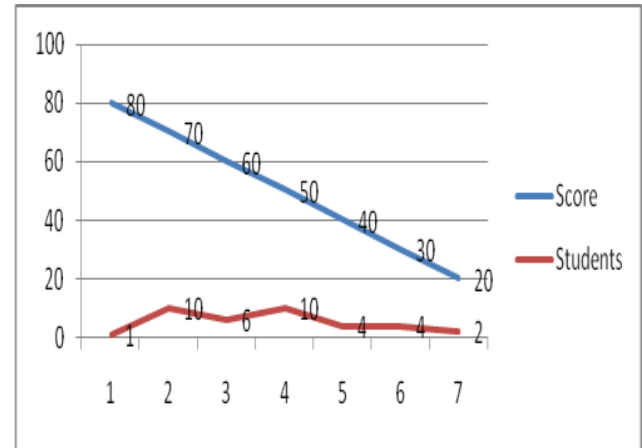

\section{Figure 4: Students' Achievement in Listening Test 4 (Cycle 1)}

As can be seen in the figure, there was only one student could achieve the highest score, 80 . Then, it was followed by ten and six students who could get 70 and 60 . In other words, the number of students who reached score over 60 was 17 , the highest number compared to the previous test result. Conversely, there were still 20 students remain in range score of 20-50. The achievement had not been in satisfactory number yet, but improvement can be seen for overall.

In completing the task given, the students were guided to apply the strategies; cognitive, meta-cognitive, and social affective strategies, for instances; in relation to the cognitive 
strategies, the students were asked to predict what information that they might need to complete the form. Then, to guide the students in applying the meta-cognitive strategies - the students were asked right away to recover when their mind wanders. In addition, the students were encouraged to have positive talk when they found the test was quite tough. Further, for social affective strategies, the students were invited to ask some questions when they found some confusion parts in the test. Through the guidance, the students show enthusiasm to do the task.

Based on the observation during the task, the students did not encounter significant problem to complete the information, even though not all of the students could successfully complete all of the 10 questions. As what can be found in the students' work sheets, the students underlined some key words in their listening activity in which showed that they had already known about what strategy that they have to apply help them in their listening comprehension test. Furthermore, the result of interview revealed that the students' strategies in their listening activities helped them a lot to figure out some problems to complete the task. Through the students' explanation, they worked on the cognitive, meta-cognitive, and socioaffected strategies in doing the task.

\section{Reflection}

After running four meeting in cycle 1, there are some important points noticed that positively influence the enhancement of the students' listening comprehension.
Despite that, some weaknesses were also found during the implementation of the listening strategies instruction.

First of all, applying listening strategies instruction in listening class contributes positively towards the students' listening performances. Previously, the students did not have any experience in doing the test and have no idea about what they have to do to figure out some challenges in the test. At the first experience doing the task, the students were very confused and almost gave up to complete the whole part of the test. However, that frustration did not stay long since the teacher explained to the students about the importance of applying listening strategies and guided them to apply the strategies. Fortunately, the students quickly understood about the strategies and gradually get used to apply the listening strategy. In addition, the students performances in listening test that they do for four times gradually showed better improvement.

Conversely, the students really depend on the researcher to remind them to apply the strategy in every number of the test that they do. This way was not really effective since the students did have self-awareness to always apply the strategies. Hence, the teachers need to make the students fully realize to always apply some listening strategies that they have to apply to help them successfully complete the listening tasks. Hence, some points need to be concerned in the next cycle:

1. Before the listening task was given to the students, the teacher proposed some listening 
comprehension problems that might be found by the students in their listening task. Then, the students were encouraged to share their ideas about what strategies need to be taken to figure out the problem. This activity was done to remind the students about what they had to do independently when they found some challenges in their listening tasks.

2. After the listening task, the students were encouraged to share their experiences in completing the task and explained the most challenge part and their strategies to figure out the challenge. This way was expected to help the students to always remember about the strategies that they have to apply in their listening activities.

In short, the research needs to go further to the second cycle by running some additional actions in relation to the implementation of listening strategies instruction.

This action was done after reflecting all actions, results of observation and interview from the first cycle. Then, some additional activities need to be implemented to enhance the students' listening comprehension performances through listening strategies instruction. Then, they cycle was run based on the following procedures:

\section{Planning}

Some preparations done in this cycle were similar to what had been done in the previous cycle. There were few additional actions added in the procedure of applying listening strategies instructions in order to prepare the students to be more aware to apply the listening strategies that they require to support their performances on listening activities and tasks.

\section{Action and Observation}

\section{The First Action (Cycle 2), $28^{\text {th }}$ November 2017}

In general, all procedures in this cycle resembles to the previous procedures in cycle 1 . However, the researcher required to emphasize about the importance of being aware and independent in applying listening strategies to support the students' performances on the their listening activities and tasks. The students were guided to apply their cognitive, metacognitive strategy, social strategy in their listening activities.

Then, the students were assigned to complete ten questions of listening IELTS part one and applied their strategies to support their listening performances. In this phase, the researcher could not clearly watch out whether the students had applied the strategy or not. However, the result of their test and small group discussion could provide information about how well the strategies helped the students' performances on their listening tasks.

Hereby, the result of the students' listening comprehension test; 


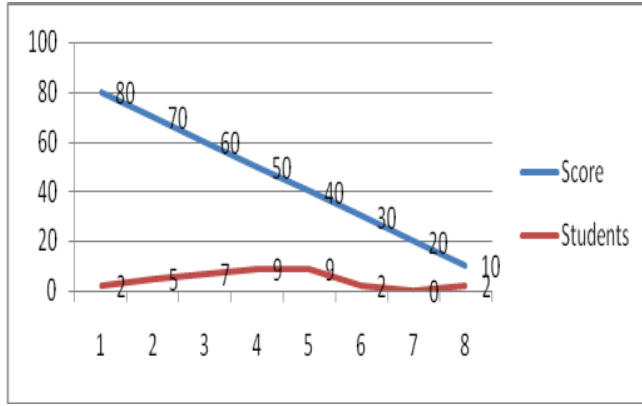

Figure 5: Students' Achievement in Listening Test 1 (Cycle 2)

As what are visible in figure, the number of students who could reach score over 50 had increased, 17 students, while some others (16 students) remained in range score of 20-50. Here, the students had shown gradual improvement on their listening performances than it was.

Despite of the improvement, the students shared that they still encountered with some unfamiliar information stated by the speaker in the audio. So, this factor influenced their performances. Even though the students had worked on their cognitive and meta-cognitive strategies, their lack of vocabulary mastery and pronunciation skill guided them into confusion in their listening. In addition, the observation activities done during the action also recorded the students' confusion because some students asked to play the audio for two times. It clearly presented the students' tough in their task.

To sum up the result of this meeting, better improvement of the students' performances could be seen here, but some problems still existed due to the students' lack of vocabulary mastery and pronunciation skill which was the core components to support their listening performances.

\section{The Second Action (Cycle 2), $2^{\text {nd }}$ December 2017}

The second meeting in cycle 2 was begun by encouraging the students to share their experiences in relation to the listening strategies that they usually apply in their reading activities. Most of them shared that they often applied their cognitive strategies, and very rarely worked on meta-cognitive, social strategies. In this case, the researcher explained in detail when each of the strategy can be effectively applied.

In listening activity, the students had to listen to audio about "library information", and complete listening test based on the audio. In the test, the students were assigned to write down one up to three words to complete a summary from the audio. Similar test format of listening test had been given to the students at the previous meetings, the students have already known about what they had to do in the test. However, the students' performances in the test was poorer compared to the other meetings. The result of the test can be seen clearly in the following table:

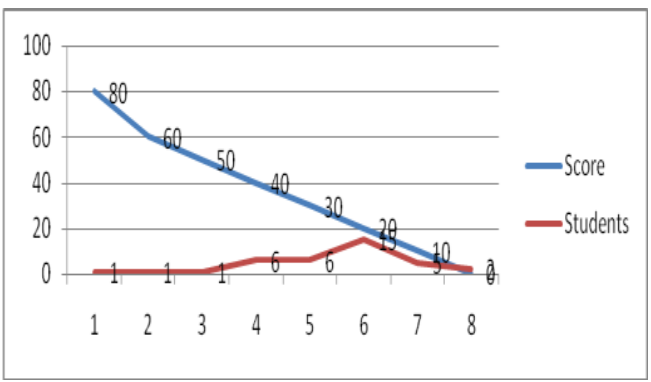

Figure 6: Students' Achievement in Listening Test 2 (Cycle 2)

Enhancing English Language Learners' Listening Comprehension through Listening Strategies Instruction 
As can be seen from the lines above, the students' achievement in the listening test was not really satisfying because there were only two of them reached 80 and 60 , while the rest could only get less than 60 , with 25 of them could only achieved 20 and 10 scores. It was the lowest achievement among the other tests. In relation to the result above, the students shared that they had listened to vey though audio to be understood. Listened at once was almost impossible for most of them to complete the test, most of the students said.

In interview session, the students said that they had tried to apply strategies that they needed to support their listening comprehension. When they applied the strategy, they could feel quiet confidence to complete all of the questions in the test, but unfortunately what they listened was not as easy as the predicted. Some other students added that the information that they had to write down was though for them because they were not really familiar with the information.

\section{The Third Action (Cycle 2), $6^{\text {th }}$ December 2017}

The third meeting was conducted by guiding the students to be consistent in applying some listening strategies that will help them in completing the task. Overall, the procedure of teaching and learning activities were run as the previous meeting. In this meeting, the students only dealt with different topic. The following figure shows the students' performance on the third listening task at the second cycle:

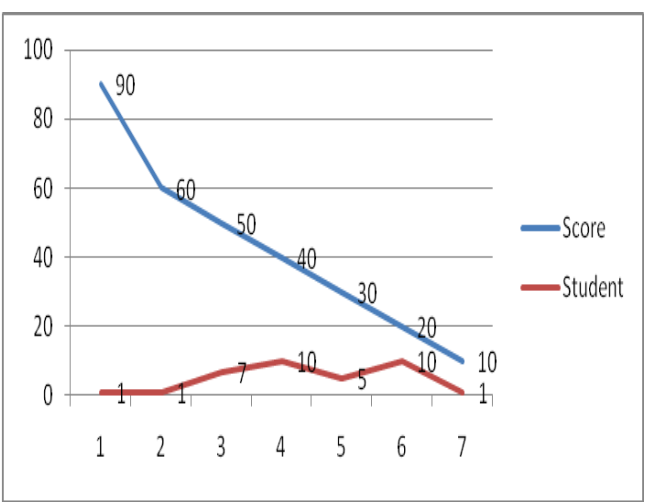

Figure 7: Students' Achievement in Listening Test 3 (cycle 2)

Based on the chart above, the most of the students performances from ten questions given indicated that the students could do the test better than before because there had been one students could reach score 90 , followed by the rest of the students got 40 up to 60 points, in which the highest number of the students could answer 4 questions correctly with 40 questions. In short, the improvement of the students performances had not been significant level, but they had made improvement, compared to the previous test result.

Through the interview, the students said that the challenges that they had in the third meeting of cycle two was not significant different from the previous test. However, in this part seemed much easier because they could guess what they had to write when they did the test, eventhough they had still failed to transfer the information that they listened into written format. The students realised that exercise would help them a lot to improve their listening skill, while the strategies can support their better performances in completing the listening task. 


\section{The Fourth Action (Cycle 2), $7^{\text {th }}$ December 2017}

At the last meeting in cycle 2, the teaching and learning activities run through guiding the students to apply some listening strategies that would be helpful to figure out their problems in understanding aural information. Cognitive, metacognitive, and social strategies were still introduced and explained to the students during the research.

In listening activities, the students had to listen to a conversation between two people, talking about "host family applicant" in which the students had to complete 10 questions based on the dialogue by writing no more than three words and/or numbers for each answer. The listening activity was done at once only, the students were required to focus on the information, apply their listening strategies, and successfully complete all of the questions. The result of the test is presented in the following information:

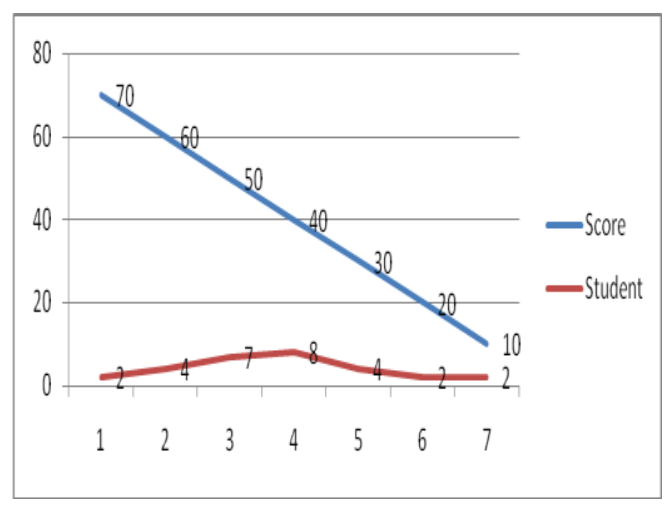

Figure 8: Students' Achievement in Listening Test 4 (Cycle 2)
The figure clearly shows the students' listening test at the last phase in cycle 2 in which presents 6 students could reach 70 and 60 . Then, it was followed by 7 students who could answer a half of the questions, with 50 score. For the rest of the students, they still stayed at score less than 50 , accounted to 16 students, in which 8 students got 80 . In short, there was slight improvement of the students' listening performances.

Based on the result of observation, the students could independently apply the listening strategies even though the result of the test did not show significant improvement. However, there had been changes of the students' learning styles. They have been already known about what they have to do in their listening activities. When they review the questions that they have to complete in the test, they could predict what they had to listen, such as they have to write some numbers, or someone's else name, or job. Meanwhile, the students sometimes got fail to transfer the verbal information into written text because they get problem in spelling. Some students said that they have already known what word or phrase that they had to write in their listening test, but then, they got confuse when writing the word. Spelling appeared as their biggest problem. The teachers explained that they required spelling practice, not only to enhance their writing skill, but also their listening skill, particularly to rewrite the information on the test. 
Reflection

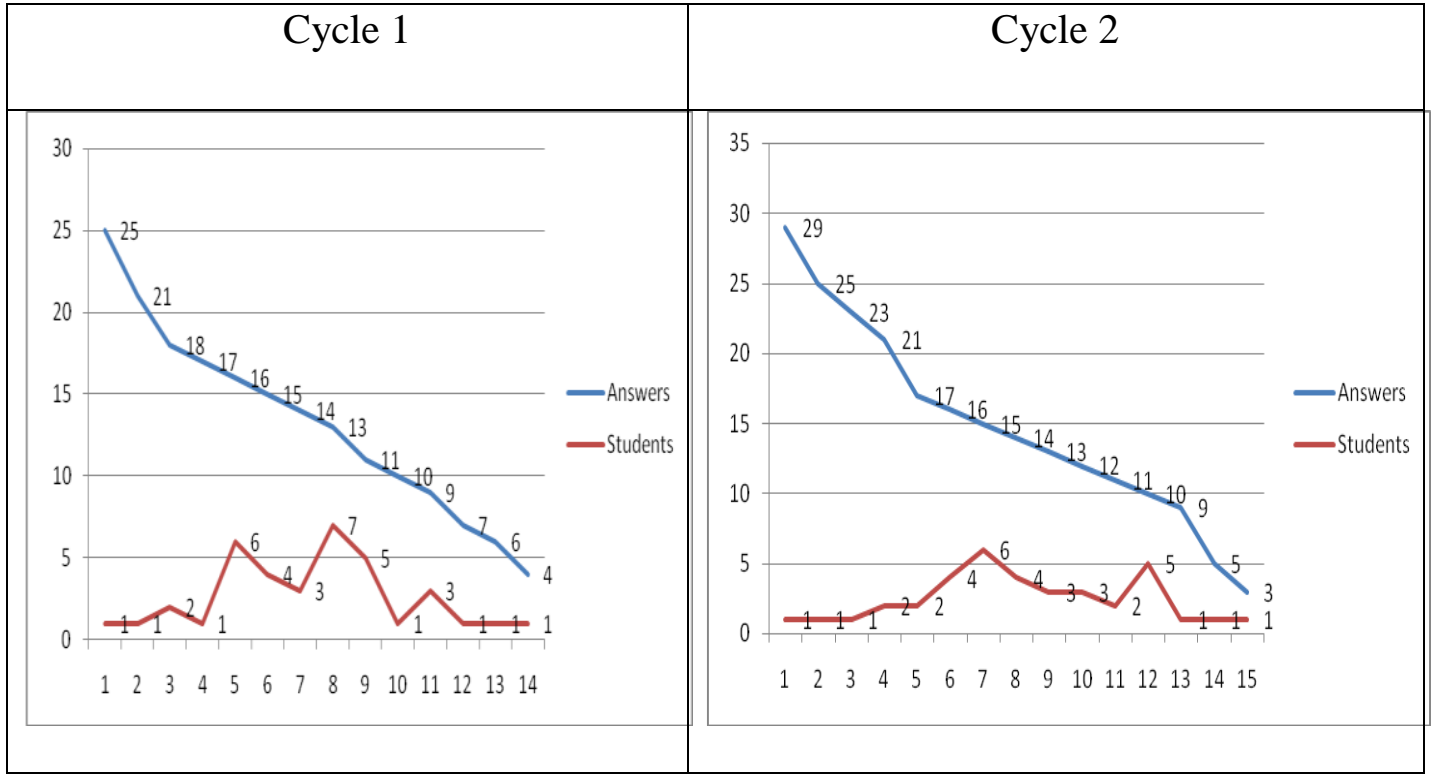

The two graphs depict the calculation of the students' performances from eight listening tasks during cycle 1 and 2. At the first cycle, the students could reach 25 out of 40 questions, in which this number is four points less than the students' achievement in cycle 2 . Then, in range 10-25 questions of correct answers in cycle 1 could be reached by 24 students, while in cycle 2, there were 32 students got correct answers at that range. Furthermore, there were 6 students could reach less than 10 questions correctly, this number is a half of the students' achievement in cycle 2 . In conclusion, there have been improvement of the students' achievements in listening tasks provided in all meetings during cycle 1 and 2.

\section{CONCLUSION}

Listening

strategies instruction applied during the research contributed to the students' performances in listening comprehension. All the strategies explained by the teachers before the students worked on their listening tasks could help them to have better achievement along the tests. In addition, the teachers' guidance about how to effectively apply the listening strategies trained them to be skillful in selecting the appropriate listening strategies to answer all questions in the test. In other words, the implementation of listening strategies instruction can positively influence the students' performances in listening activities. Hence, the teachers need to help the students to know listening strategies and guide them how to apply the strategies effectively. 


\section{REFERENCES}

Bang, Sujin \& Hiver, Phil. (2016). Investigating the structural relationships of cognitive and affective domains for L2 listening. Asian-Pacific Journal of Second and Foreign Language Education. DOI 10.1186/s40862-016-0013-8

Buck, G. (2001). Assessing

Listening. Cambridge:

Cambridge University Press.

Cross, J. (2009). Effects of listening strategy instruction on news videotext comprehension. Language

Teaching Research, 13(2), 151-176.

doi:http://dx.doi.org/10.1177/1 362168809103446.

Gilakjani, Abbas Pourhosein and Ahmadi, Mohammad Reza. 2011. A Study of Factors Affecting EFL Learners' English Listening Comprehension and the Strategies for Improvement. Journal of Language Teaching and Research, Vo. 2, No. 5, pp. 977-988, September 2011.doi: 10.4304/jltr.2.5.977-988.

Goh, C., and T. Yusnita (2006). Metacognitive instruction in listening for young learners. ELT Journal 60(3):222-232.

Hadijah \& Shalawati. 2017. Listening Comprehension Hindrances of EFL (English
Foregin Language) Learners on 2016/2017 Academic Year in English Study Program at Universitas Islam Riau. $J$ SHMIC (Journal of English for Academic). Vol. 4, No. 1 August 2017.

Malkawi, Abeer H. 2010. Listening Comprehension for Tenth Grade Students in Tabaria High Schools for Girl. Journal of Language Teaching and Research, Vol. 1, No. 6., pp 771-775, November 2010. doi:10.4304/jltr.1.6.771-775.

Mohseny, A., \& Raeisi, N. (2009). The Relationship between Language Proficiency of EFL Students and Their Strategy Use in Listening Comprehension. TEFLL, 1(4), 111-132.

Nogueroles López, M. (2017). Listening Strategies Instruction: effects on Hong Kong students' general strategic behavior. Asian Pacific Journal of Second and Foreign Language Education. DOI 10.1186/s40862-0170029-8

Yeldham, M., \& Gruba, P. (2014). Toward an instructional approach to developing interactive second language listening. Language Teaching Research, 18(1), 33-53. doi:http://dx.doi.org/10.1177/1 362168813505395 
Graham, S., Santos, D., \& Vanderplank, R. (2011). Exploring the relationship between listening development and strategy use. Language Teaching Research, 15(4), 435-456.

doi:http://dx.doi.org/10.1177/1 362168811412026

Oxford, R. L. (2011). Teaching and researching language learning strategies. Harlow: Longman/Pearson Education. https://search.proquest.com/docview/ $\underline{1547694998 ? \text { accountid }=62695}$

Vandergrift, Larry. (2007). Language Teaching. Recent development in second and foreign language listening comprehension research, page 191-210. United Kingdom: Cambridge University Press. doi:10.1017/S02614448070043 38 